\title{
Roe Deer Mortality Due to Mechanization of Work in Agrocenoses ${ }^{1}$
}

\author{
Jan KAŁUZIŃSKI
}

Kałuziński J., 1982: Roe deer mortality due to mechanization of work in agrocenoses. Acta theriol., 27, 30: 449-455 [With 2 Tables].

Examination was made of the extent of losses in a roe deer population (Capreolus capreolus (Linnaeus, 1758)) caused by mechanical equipment used in agriculture. The studies were carried out in an area in which agrotechnical work was highly mechanized and the density of roe deer was relatively high $(7 / 100 \mathrm{ha})$. Annual losses were about 1.3 individuals per each 100 ha of the experimental range. Only the young roe deer were killed. Every year $26 \%$ of the natural increase of roe deer population was calculated to be lost as the result of mechanized agricultural operations.

[Polish Hunting Association, Research Station, 62-055 Czempiń, Poland]

\section{INTRODUCTION}

Many of the animal species inhabiting agrocenoses are exposed to danger from the agrotechnical work carried out there. Mechanization of soil and plant cultivation and of harvesting operations in many cases creates threat to the life of these animals, not excluding game species (Hell, 1967, 1969; Kałuziński \& Pielowski, 1976). The specific behaviour of young animals, for instance crouching down on the ground when encountering danger, is characteristic of chicks of gallinaceous birds, suckling hares and roe deer fawns, and this has a decisive effect on the amount of losses. In certain game species, however, some degree of adaptation has been found to the new ecological situation in the difficult habitat for game animals formed by cultivated field (Kałuziński, 1971; Pielowski, 1970, 1977; Bresiński, 1981).

There is therefore a need to obtain more information on losses caused by agricultural mechanization and the effect of such losses on population dynamics of the different species. An exact knowledge of the extent of losses and the mechanisms creating them would in addition form a starting point in the search for solutions aimed at reducing such losses. Detailed Polish studies on this subject are concerned with the hare only (Nabiałczyk 1961, 1966; Puszkar, 1970; Kałuziński \& Pielowski, 1976). There is however, no analogical information on the roe deer, Capreolus

${ }^{1}$ Praca wykonana w ramach problemu MR-II/15 koordynowanego przez Instytut Ekologii PAN. 
capreolus, which is occurring in increasing numbers in fields (Kałuziński, 1974; Pielowski, 1977; Zejda, 1978). One of the more important problems in management of this species is to ascertain the extent and if possible to counteract the mortality among these animals, since correct management of the roe deer population should be based on reliable data as to numbers, realized production and mortality in the population.

The purpose of the present study is to estimate losses in the roe deer population caused by mechanical equipment used in agrotechnical operations. Collection of such data is essential in order to analyze changes in numbers, to draw up annual balances and models for optimum management of the population.

\section{STUDY AREA AND METHODS}

The studies were carried out in the experimental area 13,500 ha in extent of the Research Station of the Polish Hunting Association at Czempin. This range is situated in the western part of Poland and is characterized by a low degree of tree stands (about 7\%) (Bresiński \& Chlewski, 1976). The cultivated fields are maintained in a state of intensive cultivation, with predominance (about $70 \%$ ) of mass production system. The land is under cultivation by modern State Farm Groups and production co-operatives, and also well-run individual farms differing cnly slightly from the state farms in their degree of mechanization. All the farms carry on intensive animal production, and consequently a high percentage of the land is devoted to production of green fodder, hay and silage.

Populations of game species living in this region have been studied for many years. The numbers of roe deer on an average for the last 13 years has been 7 individuals per 100 ha during the spring period (Kałuziński, 1982).

Predators capable of affecting the population of roe deer in this study area are numerous foxes (Pielowski, 1976) and stray dogs. Further details on this area to be found in the study by Kałuziński (1982).

The studies were carried out from 1977-1980. Losses among roe deer can only be caused during the period when rapidly-moving mechanical equipment is being used during spring harvesting of green forage and mowing of rape. In this connection observations were carried out for four successive years on selected study areas (Table 2) during the course of the above field work. The areas were chosen so as to ensure relatively equal cover of the whole study area. Observations intended to ascertain actual losses among roe deer were carried out while riding on the machines in operation, following them on foot or on horseback.

After completing the work, which lasted in each study area from several hours to two or three days, a report was drawn up containing, in addition to the data and working time of the machines, the number of roe deer killed. As the majority of them were injured by the cutting parts of the mowing machines, it was only possible to estimate the animals' age.

\section{RESULTS}

Before starting to estimate losses in the roe deer population caused by agrotechnical operations, the kinds of area in which females with 
their young are present in spring were established by means of observations. Data on the extent of these crops over the whole study area were obtained by interviews (Table 1), and the same method was used for the area covered by crops, which is included in intensive agrotechnical operations during the period from the second 10-day period of April to the third 10-day period of June (that is, the period during which the fawns were born). This made it possible to define the size of the area in which potential danger to roe deer occurs as the result of agrotechnical operations (Table 1). The actual average number of born per year, is

Table 1

Area of crops in which roe deer occur and in which they are in danger over the period from 15th April to 20th June.

\begin{tabular}{lrrr}
\hline \multicolumn{1}{c}{ Kind of culture } & $\begin{array}{c}\text { Inhabited by } \\
\text { deer, ha }\end{array}$ & \multicolumn{2}{c}{ Threatened } \\
\cline { 3 - 4 } Rye & 1672 & 886 & per cent \\
Barley & 1067 & 0 & 53 \\
Wheat & 1132 & 0 & 0 \\
Rape & 645 & 645 & 100 \\
Lucerne & 746 & 746 & 100 \\
Meadows & 1021 & 1021 & 100 \\
Other green forage & 397 & 397 & 100 \\
Other field shelters (clusters of & 256 & 0 & 0 \\
$\quad$ trees and bushes) & 1027 & 0 & 0 \\
Forests & 7963 & 3695 & 46 \\
Total & 5537 & 0 & 0 \\
Others kinds of culture & & & 0 \\
\hline
\end{tabular}

711 individuals (Kałuziński, 1982). On account of objectives difficulties in establishing the actual number of roe deer living in spring in different kinds of crops it was taken that these animals occupy them to an equal degree. Calculation was made on this basis that 329 individuals, that is $46 \%$ of the young roe deer born, are endangered by mechanical equipment working in fields to harvest green fodder.

On an average 46 roe deer were killed each year in the study areas (Table 2 ), $85 \%$ of which were fawns from one to 10 days old. The remainder, that is, $15 \%$, were older individuals, but of these the oldest fawns were not more than 2 weeks old.

The data obtained on the amount of losses among roe deer in the study areas was calculated per 100 ha of the various crops. A knowledge of the proportion of the given crop in the total area made it possible in turn to calculate losses from the combined area and whole study area, this figure being on an average 185 roe deer annually (Table 2). The combined area in which danger to roe deer was present was 3695 ha, that is, $46 \%$ of the total area (Table 1). Thus on each 100 ha in which 
agrotechnical operations are carried out in spring 5 roe deer are killed. Losses are not equal in the different kinds of crops, the greatest losses being found during harvesting winter rye for silage and the first mowing of lucerne, medium losses when mowing meadows and other green fodder crops, and smallest during mowing of rape (Table 2).

Table 2

Average losses among young roe deer caused by agrotechnical operations in different kinds of crops.

\begin{tabular}{|c|c|c|c|c|c|}
\hline \multirow[b]{2}{*}{ Kind of culture } & \multirow{2}{*}{$\begin{array}{l}\text { No. of } \\
\text { sample } \\
\text { areas }\end{array}$} & \multirow{2}{*}{$\begin{array}{l}\text { Total size } \\
\text { of sample } \\
\text { areas, ha } \\
\text { (min-max) }\end{array}$} & \multicolumn{3}{|c|}{ Losses } \\
\hline & & & $\begin{array}{c}\text { On sample } \\
\text { areas }\end{array}$ & $\begin{array}{l}\text { Per } \\
100 \text { ha }\end{array}$ & $\begin{array}{l}\text { The whole } \\
\text { area }\end{array}$ \\
\hline Rye & 6 & $\stackrel{90}{(8-25)}$ & 7 & 7.7 & 68 \\
\hline Meadows & 13 & $\begin{array}{l}418 \\
(9-100)\end{array}$ & 13 & 3.1 & 32 \\
\hline Lucerne & 4 & $\begin{array}{c}106 \\
(10-60)\end{array}$ & 8 & 7.5 & 56 \\
\hline Other green forage & - 7 & $\begin{array}{c}187 \\
(9-100)\end{array}$ & 9 & 4.8 & 19 \\
\hline Rape & 13 & $\begin{array}{c}582 \\
(20-70)\end{array}$ & 9 & 1.5 & 10 \\
\hline Total, Average & 43 & 1383 & 46 & 4.9 & 185 \\
\hline
\end{tabular}

The number of endangered young roe deer in the whole area is known from previously presented data (329 individuals). In fact 185 youngs are killed, that is, $56 \%$ of the total number endangered.

Knowing the average number of roe deer born in the study area, estimated at 711 individuals (Kałuziński, 1982), it is possible to calculate the amount of losses for the whole population. Thus $26 \%$ of the natural production of roe deer population $(711: 185)$ is lost as the result of the agrotechnical operations carried out.

\section{DISCUSSION}

It is interesting to know to what degree losses from natural production of roe deer ( $26 \%$ of the number born) caused by mechanical equipment used in agriculture affect population dynamics. In the same area the combined reduction in production of roe deer is about $56 \%$ of the number born (Kałuziński, 1982), and thus agrotechnical operations are responsible for about half of this reduction. This fact has therefore a directly decisive effect on variations in population numbers. In attempting to limit the high mortality rate among young roe deer attention must be given in the first place to such agrotechnical operations.

The considerable differences in the amount of losses in different crops 
depend to a great extent on the intensity of the agrotechnical operation carried out. As rye mown for silage gives place to potatoes and maize, there is enormous concentration of equipment on such areas in order to carry out the operation as quickly as possible. The roe deer are not able to lead out their fawns, even when several days old, from very extensive fields of rye. In fact if harvesting of green crops from the given area takes place within one day, it is to be expected that all the young roe deer will be killed. If, however, the operation is carried out over the course of two or three days, there is a possibility that some of the mothers may succeed in withdrawing their young from the danger area. The same applies to lucerne fields. The green mass of this plant is readily used for production of dried fodder, and the intensity of the operation most often leads to total loss of fawns.

The losses are negligible if harvesting of green fodder takes place successively for the current fodder requirements of cattle and pigs. Utilization of the area occupied by the green crop is then considerably prolonged in time, which enables the animals successfully to escape the danger.

Losses in head of roe deer become more intensive when harvesting of green crops and birth of fawns coincide in time. Harvesting of the first green crop begins during the first ten days of May, and with the hay harvest in meadows lasts throughout the whole of June. The peak period of births of fawns also occurs during this period (Pielowski, 1970; Strandgaard, 1972). Such losses will occur each year to a similar degree if no effective counteraction is undertaken. In the large amount of popular science literature on the roe deer details are given of several methods aimed at preventing the losses which occur during harvesting of green crops, but they are not however, applied in game management.

It may be concluded from the foregoing that the amount of losses among roe deer depends to a great extent on the structure of field crops in the given range. The greater the area of green fodder crops intended for spring-summer harvesting, the greater the losses. Predominance of cereal crops, the final effect of which is to be grain, will contribute to reduction in losses.

\section{REFERENCES}

1. Bresiński W. \& Chlewski A., 1976: Tree stands in fields and spatial distribution of hare populations. [In: "Ecology and management of European hare populations", Eds. Pielowski Z. \& Pucek Z.]. Państw, Wyd, Roln, i Leśne: 185-193. Warszawa, 
2. Bresiński W., 1981: Stadowość u sarn polnych (Caprealus capreolus) jako wyraz przystosowania do bytowania w warunkach krajobrazu rolniczego. $\mathrm{Ph}$. D. Theses, Inst. Appl. Zool. Agric. Acad. Poznań: 1-45.

3. Hell P., 1967: Vplyv intenzivnej velkoplosnej rastlinnej vyroby na populaciu polovnej zveri. Ceskoslovenska ochrana prirody. 8: 109-126. Bratislava.

4. Hell P., 1969: Prispevok k poznaniu vplyvu mechanizovanej rastlinnej vyroby na populaciu uzitkovej polnej polovnej zveri. Acta zootechnica. Univers, agricult. - Nitra, 15.

5. Kałuziński J., 1971: Badania nad zającem. Mechanizacja rolnictwa a pogłowie zajęcy. Łowiec pol., 11 (1398): 2.

6. Kałuzinski J., 1974: The occurrence and distribution of field ecotype of roe deer in Poland. Acta theriol., 19: 291-300.

7. Kałuziński J. \& Pielowski Z., 1976: The effect of technical agricultural operations on the hare population. [In: "Ecology and management of European hare populations”, Eds. Z. Pielowski \& Pucek Z.]. Państw. Wyd. Roln. i Leśne: 205-211. Warszawa.

8. Kałuziński J., 1982: Dynamics and structure in a field roe deer population. Acta theriol., 27: 385-408.

9. Nabiałczyk T., 1966: Zwierzyna a mechanizacja rolnictwa. Łowiec pol., 15 (1282): $2-4$.

10. Nabiałczyk T., 1966: Szkody w zwierzynie wyrządzane przez sprzęt mechaniczny. Zach. Por. low., 7: 25-36. Poznań.

11. Puszkar T., 1970: Wpływ rodzaju zabiegów agrotechnicznych i sposób ich przeprowadzania na warunki bytowania zajęcy (Lepus europaeus Pallas, 1778) w agrocenozach. Ph. D. Theses, Inst. Ecol. PASci.: 1-23. Warszawa.

12. Pielowski Z., 1977: Das Feldreh - Wild der Zukunft in der Agrarlandstschaft. Beitr. zur Jagd- und Wildforsch., 10: 193-200.

13. Pielowski Z., 1970: Sarna. Monografia przyrodniczo lowiecka. Państw. Wyd, Roln. i Leśne: 1-120. Warszawa.

14. Pielowski Z., 1976: The role of foxes in the reduction of the European hare population. [In: "Ecology and management of European hare populations", Eds. Z. Pielowski \& Z. Pucek]. Państw. Wyd. Roln. i Leśne: 135-148. Warszawa.

15. Strandgaard H., 1972: An investigation of corpora lutea, embryonic development, and time of birth of roe deer (Capreolus capreolus) in Denmark. Danish Rev. Game Biol., 6, 7: 1-22.

16. Zejda J., 1978: Field groupings of roe deer (Capreolus capreolus) in a lowland region. Folia zool., 27, 2: 111-122.

Accepted, March 15, 1982.

Jan KAEUZINSSKI

\section{SMIERTELNOSC SARN W WYNIKU MECHANIZACJI PRAC ROLNYCH}

\section{Streszczenie}

Celem pracy jest ocena wielkości strat w populacji sarn Capreolus capreolus (Linnaeus, 1758), spowodowanych prze stosowany przy zabiegach agrotechnicznych sprzęt mechaniczny. Badania prowadzono na terenie charakteryzującym się wysokim stopniem mechanizacji wszystkich prac rolniczych, a jednocześnie zasiedlonym przez liczną populację sarn, od szeregu lat znajdującą się pod ścisłą kontrolą. 
Badania wykonano w latach 1977-1980. Przeprowadzono je na 129 powierzchniach kontrolnych, których łączna wielkość w jednym roku wynosiła 1383 ha. Obserwacjami objęto pracę maszyn (zbierających lub koszących zielonki i rzepak) w czasie wykonywania której powstają straty w populacji sarn.

$\mathrm{Na}$ podstawie znajomości struktury upraw polnych i powierzchni objętych wiosną intensywnymi zabiegami agrotechnicznymi ustalono, że potencjalne zagrożenie życia sarn w każdym roku ma miejsce na ca $46 \%$ terenu doświadczalnego (Tabela 1).

Uzyskane dane odnośnie strat wśród sarn na powierzchniach kontrolnych przeliczono na 100 ha poszcególnych upraw, a te z kolei na łączny areał danej uprawy. Ustalono, że roczne straty wynoszą średnio 185 sarn, co stanowi 1,3 osobnika na każde 100 ha lowiska doświadczalnego (Tabela 2). Giną wyłącznie sarny młode w pierwszych dniach życia.

Wyliczono, że na terenie doświadczalnym wskutek stosowanych zabiegów agrotechnicznych ginie rocznie $26 \%$ przyrostu naturalnego. $\mathrm{Na}$ tej podstawie można sformułować stwierdzenie, że agrotechnika jest czynnikiem znacznie obniżającym efektywny przyrost naturalny sarn, a zatem wydatnie wplywa na ograniczenie liczebności populacji bytujących w krajobrazie rolniczym. 